\title{
PENGGUNAAN BERBAGAI SUMBER KARBOHIDRAT \\ UNTUK PEMBUATAN SILASE RUMPUT GAJAH (Pennisetum purpureum) \\ (Use Of Various Sources Of Carbohydrates For Making An Elephant Grass (Pennisetum purpureum) Silage)
}

\author{
Daryatmo, J. ${ }^{1)}$, Suharti ${ }^{2)}$ dan Rohani, S. ${ }^{3)}$ \\ ${ }^{1)}$ Sekolah Tinggi Penyuluhan Pertanian Magelang \\ J1. Magelang-Kopeng Km 7 Purwosari Tegalrejo Magelang 56192 \\ e-mail: jkodr@yahoo.com \\ ${ }^{2)}$ Balai Penyuluhan Pertanian Haruyan, \\ Hulu Sungai Tengah, Kalimantan Selatan
}

Diterima : 22 Januari 2017

Disetujui : 17 Mei 2017

\begin{abstract}
ABSTRAK
Penelitian dilakukan untuk mengetahui pengaruh penggunaan berbagai sumber karbohidrat terhadap komposisi kimia dan organoleptik silase rumput Gajah. Penelitian dilakukan dengan menggunakan rancangan acak lengkap (RAL) terdiri dari 4 perlakuan yaitu: P0 (rumput gajah 100\%) sebagai kontrol, P1 (rumput gajah+molases), P2 (rumput gajah+dedak), P3 (rumput gajah+gula pasir), dengan 4 ulangan. Variabel yang diamati adalah: warna, rasa, bau, $\mathrm{pH}$, dan kondisi fisik. Hasil pengamatan menunjukkan bahwa perlakuan P1 (rumput gajah+tetes) merupakan komposisi yang terbaik untuk menghasilkan silase berdasar pada pengamatan organoleptik maupun komposisi kimia.
\end{abstract}

Kata kunci: Rumput, Pennisetum purpureum, silase, karbohidrat

\begin{abstract}
The study was conducted to determine the effect of the use of various sources of carbohydrates to the chemical composition and organoleptic of elephant grass silage. The study was conducted using a completely randomized design (CRD) consisting of 4 treatment are: PO (Elephant grass (Pennisetum purpureum) 100\%) as a control, P1 (elephant grass +molasses), P2 (elephant grass +rice bran), P3 (elephant grass + white sugar), with 4 replications. The variables measured were: color, taste, odor, $p H$, and physical condition. The results showed that treatment P1 (elephant grass+molasses) is the best composition to produce silage based on the observation of the organoleptic and chemical composition.
\end{abstract}

Keywords: Grass, Pennisetum purpureum, silage, carbohydrates 


\section{PENDAHULUAN}

Ketersediaan hijauan pakan di Indonesia merupakan tema utama yang menjadi pembatas perkembangan ternak. Salah satu komponen pakan yang utama adalah hijauan karena hijauan merupakan bahan pakan utama (lebih dari 80 persen dari total bahan kering).

Penyediaan pakan hijauan merupakan salah satu faktor penentu keberhasilan dalam usaha peternakan ternak ruminansia (sapi, kambing, kerbau dan domba). Terdapat sejumlah permasalahan terkait dengan pakan ternak. Pertama, mutu pakan yang variatif (cenderung kurang) karena pakan kebanyakan merupakan limbah lignoselulolitik dengan kadar Total Digestible Nutrient (TDN) dan protein yang rendah. Kedua, produksi pakan musiman (seasonal movement), umumnya produksi akan menurun ketika musim kemarau, yaitu pada bulan April hingga September. Pada bulan tersebut peternak akan kesulitan mendapatkan rumput lapang atau penurunan produksi pada hijauan yang dibudidayakan sehingga produksi yang berlimpah pada musim hujan perlu diawetkan dan disimpan untuk digunakan pada musim kemarau. Dengan demikian, membutuhkan teknologi konservasi hijauan.

Rumput Gajah adalah tanaman yang termasuk ke dalam kelompok tanaman rumput-rumputan. Rumput gajah banyak dimanfaatkan pada bidang peternakan yaitu sebagai pakan ternak seperti sapi, kambing, domba, dan kuda. Umumnya rumput gajah yang digunakan di Indonesia adalah rumput yang tumbuh secara liar. Namun untuk peternakan yang relatif besar maka rumput yang digunakan adalah rumput yang sengaja ditanam atau dipelihara secara khusus. Hal ini dilakukan untuk memenuhi kebutuhan pakan ternak.

\section{MATERI DAN METODE}

Lokasi pengkajian pembuatan silase rumput gajah dilaksanakan di Lab. Pengolahan Pakan dan Kebun Rumput STPP Magelang, dan analisa proksimat dilakukan di Laboratorium PT. Sido Agung Magelang.

\section{Materi}

Bahan yang di pakai untuk pelaksanaan pengkajian pembuatan silase rumput gajah adalah : a) rumput gajah 80 $\mathrm{kg}, \mathrm{b}$ ) molasses (tetes) 1 liter, c) bekatul 1,6 $\mathrm{kg}$, dan d) gula pasir $1 \mathrm{~kg}$. Alat yang digunakan dalam pelaksanaan pengkajian ini adalah: a) Timbangan duduk kapasitas $15 \mathrm{~kg} 1$ buah, b) ember ukuran 10 liter 1 buah, c) alat pemotong rumput makanan ternak (Chopper) 1 buah, d) silo (kantong plastik) 0,8 mm 1 rol, e) karet pengikat (tali rafia), f) karung kapasitas $50 \mathrm{~kg} 12$ buah, g) drum plastik kapasitas 100 liter 2 buah, h) terpal ukuran $4 \times 5 \mathrm{~m}$, i) gunting, j) kamera digital canon 1 buah, k) Kertas Lakmus (pH meter). Sedangkan alat yang digunakan membuat tepung silase untuk uji proksimat adalah : a) oven, b) kertas koran, c) lakban, d) saringan, e) blender, dan f) plastik pembungkus tepung.

\section{Metode}

Penelitian menggunakan rancangan acak lengkap (RAL) dengan 4 perlakuan dan 4 ulangan. Perlakuan penelitian terdiri dari: $\mathrm{P} 0=$ Rumput Gajah tanpa penambahan sumber karbohidrat (kontrol); P1= Rumput Gajah+tetes; P2= Rumput Gajah+bekatul; P3=Rumput Gajah+gula pasir. Selanjutnya dilakukan pengamatan meliputi: a) Pengamatan organoleptik (warna, bau, 
tekstur, rasa, dan $\mathrm{pH}$ ), dan b) Komposisi kimia (protein kasar, serat kasar dan kadar air). Data yang didapatkan lalu dianalisis statistik. Apabila perlakuan berpengaruh nyata, dilanjutkan dengan uji Beda Nyata Terkecil (Steel dan Torrie, 1994).

\section{HASIL DAN PEMBAHASAN}

\section{Komposisi Kimia}

Tabel 1. Komposisi kimia silase rumput gajah pada 4 perlakuan yang berbeda1.

\begin{tabular}{llcccc}
\hline No & \multicolumn{1}{c}{ Perlakuan } & $\begin{array}{c}\text { Protein kasar } \\
(\mathbf{\%})\end{array}$ & $\begin{array}{c}\text { Serat kasar } \\
(\mathbf{\%})\end{array}$ & $\begin{array}{c}\text { Kadar } \\
\text { Air } \\
(\boldsymbol{\%})\end{array}$ & $\begin{array}{c}\text { Bahan } \\
\text { kering } \\
(\boldsymbol{\%})\end{array}$ \\
\hline 1 & P0 (kontrol) & 5,939 & 31,231 & 14,040 & 85,960 \\
2 & P1 (tetes) & 7,944 & 28,537 & 13,030 & 86,970 \\
3 & P2 (dedak) & 7,679 & 26,745 & 12,300 & 87,700 \\
4 & P3 (gula pasir) & 6,820 & 28,446 & 5,384 & 94,616 \\
\hline
\end{tabular}

${ }^{1}$ Analisis Laboratorium PT. Sido Agung Magelang

\section{Protein Kasar (PK)}

Dari hasil yang diperoleh rumput gajah yang dibuat silase tanpa bahan tambahan (P0) sebagai kontrol, nilai protein $5,938 \%$, jika dibandingkan dengan kandungan protein rumput gajah segar 8,69\% (Hartadi et al., 1993), terjadi penurunan protein kasar sebesar 2,752\%.

Pada pembuatan silase dengan perlakuan menggunakan bahan tambahan molasses (P1) mempunyai nilai protein kasar yaitu 7,944\%, jika dibandingkan dengan rumput gajah segar yang memiliki nilai protein kasar sebesar 8,69\% (Hartadi et al., 1993), terlihat mengalami penurunan nilai protein kasar hanya sekitar $0,746 \%$.

Pembuatan silase dengan menggunakan bahan tambahan dedak (P2), memiliki kandungan protein $7,679 \%$ dibandingkan dengan nilai protein kasar rumput gajah segar yaitu $8,69 \%$ (Hartadi et al., 1993), penurunan nilai protein kasar sebesar $1,011 \%$. Sedangkan pembuatan silase rumput gajah dengan bahan tambahan gula pasir (P3) memiliki kandungan protein kasar sebesar $6,820 \%$, jika dibandingkan dengan kandungan protein kasar pada rumput gajah segar yaitu $8,69 \%$ (Hartadi et al., 1993), juga mengalami penurunan kandungan protein kasar sebesar 1,87\%.

\section{Serat Kasar (PK)}

Pembuatan

silase tanpa menambahkan bahan pengawet (P0) memiliki kandungan serat kasar sebesar $31,231 \%$, jika dibandingkan dengan kandungan nutrisi serat kasar rumput gajah segar 31,2 \% (Sutardi, 1981), kandungan serat kasar antara rumput gajah segar dengan silase rumput gajah tidak mengalami penurunan.

Pada pembuatan silase rumput gajah dengan menggunakan bahan tambahan molasses (P1) mempunyai kandungan serat kasar $28,537 \%$ dari sebelum diolah atau saat segar yaitu 31,2\% (Sutardi, 1981), terjadi penurunan nilai serat kasar sebesar $2,663 \%$,

Perlakuan yang selanjutnya adalah dengan menggunakan bahan tambahan dedak (P2) yang mempunyai kandungan serat kasar 26,745 jika dibandingkan dengan kandungan serat kasar rumput gajah segar yaitu 31,2\% (Sutardi, 1981), penurunan nilai serat kasar sekitar $4,455 \%$.

Silase dengan menggunakan bahan tambahan gula pasir (P3) memiliki nilai 
serat kasar sebesar 28,446\%, dibandingkan dengan kandungan serat kasar rumput gajah segar yaitu 31,2\% (Sutardi, 1981), penurunan nilai serat kasar sekitar 2,754\%.

\section{Kadar air}

Hasil kadar air pada rumput gajah tanpa menggunakan bahan tambahan (P0) adalah $14,040 \%$, sedangkan pada bahan tambahan tetes (P1) yaitu 13,030\%. Penambahan bahan lainnya adalah dengan dedak (P2), mempunyai kadar air sebesar $12,300 \%$. Perlakuan terakhir adalah dengan menambahkan bahan gula pasir (P3), kadar air adalah 5,384\%. Kadar air pada penambahan gula pasir cukup rendah dan paling sedikit kadar airnya dibandingkan 3 perlakuan lainnya (kontrol, molasses, dan dedak).

\section{Pengamatan Organoleptik}

Pengamatan organoleptik silase rumput gajah meliputi: Tekstur, warna, bau, rasa, $\mathrm{pH}$, dan kondisi fisik yang terlihat dari silase itu sendiri.

\section{Tekstur}

Hasil penilaian tekstur silase pada 4 perlakuan tertuang dalam Tabel 3 dibawah ini :

Tabel 2. Rerata karakter fisik tekstur silase rumput gajah pada berbagai perlakuan

\begin{tabular}{clcl}
\hline No & \multicolumn{2}{c}{ Tekstur } & \multicolumn{1}{c}{ Keterangan } \\
\cline { 2 - 4 } Perlakuan & $3^{\mathrm{a}}$ & $\begin{array}{l}\text { Lunak, basah/sedikit berair, dan tidak } \\
\text { menggumpal }\end{array}$ \\
\hline 1 & P0 (kontrol) & $3,5^{\mathrm{a}}$ & $\begin{array}{l}\text { Lunak, basah/sedikit berair, dan tidak } \\
\text { menggumpal }\end{array}$ \\
3 & P1 (tetes) & $3,5^{\mathrm{a}}$ & $\begin{array}{l}\text { Lunak, basah/sedikit berair, dan tidak } \\
\text { menggumpal } \\
\text { Lunak, lembut/kering, dan tidak menggumpal }\end{array}$ \\
4 & P2 (dedak) & $5^{\mathrm{b}}$ & $\begin{array}{l}\text { Lula pasir) } \\
{ }^{\mathrm{a}, \mathrm{b}} \text { Superscript yang berbeda pada kolom yang sama menunjukkan perbedaan yang nyata }(\mathrm{P}<0,05)\end{array}$
\end{tabular}

Berdasarkan analisis statistik pada karakter tekstur terlihat antara $\mathrm{P} 0, \mathrm{P} 1$, dan P2 berbeda tidak nyata. Tekstur yang dihasilkan adalah lunak, basah/sedikit berair, dan tidak menggumpal. Sedangkan P3 dibandingkan dengan $\mathrm{P} 0, \mathrm{P} 1$, dan $\mathrm{P} 2$ terlihat berbeda nyata $(\mathrm{P}<0,05)$ dan tekstur yang dihasilkan adalah lunak, lembut/kering, dan tidak menggumpal. Dari segi tektur perlakuan dengan gula pasir (P3) lebih unggul dan sesuai dengan pendapat Siregar (1996) bahwa, secara umum silase yang baik mempunyai ciri-ciri yaitu tekstur masih jelas seperti alamnya.

\section{Warna}

Dari hasil rekapitulasi penilaian karakter warna dituangkan dalam Tabel 4 berikut ini:

Tabel 3. Rerata karakter fisik warna silase rumput gajah pada berbagai perlakuan

\begin{tabular}{|c|c|c|c|}
\hline \multirow[t]{2}{*}{ No } & \multicolumn{2}{|c|}{ Warna } & \multirow[t]{2}{*}{ Keterangan } \\
\hline & Perlakuan & Rerata skor & \\
\hline 1 & P0 (kontrol) & $3,5^{\mathrm{a}}$ & Coklat agak kehitaman \\
\hline 2 & P1 (tetes) & $4,5^{\mathrm{a}_{1}}$ & Hijau muda \\
\hline 3 & P2 (dedak) & $3,5^{a_{b}}$ & Hijau tua \\
\hline 4 & P3 (gula pasir) & $5^{b}$ & Hijau kekuningan \\
\hline
\end{tabular}


Berdasarkan analisis data statistik terlihat bahwa P3 mempunyai warna hijau kekuningan dan lebih baik karena berbeda nyata $(\mathrm{P}<0,05)$ dari $\mathrm{P} 1$ yang warnanya hampir mendekati coklat. Sementara pada P1 dan P2 terlihat berbeda tidak nyata atau sama saja, warna yang terlihat adalah warna hijau namun beda pada konsentrasi hijaunya (P1 yaitu hijau muda dan P2 yaitu hijau tua).

Sesuai dengan pendapat Yusriani (2015), ciri silase yang baik adalah hijau kekuningan. Selain itu Reksohadiprodjo (1998), menambahkan bahwa perubahan warna yang terjadi pada tanaman yang mengalami proses ensilase disebabkan oleh proses respirasi aerobic yang berlangsung selama persediaan oksigen masih ada, sampai gula tanaman habis. Gula akan teroksidasi menjadi $\mathrm{CO} 2$ dan air, panas juga dihasilkan pada proses ini sehingga temperature naik. Temperature yang tidak dapat terkendali akan menyebabkan silase berwarna coklat tua sampai hitam. Hal ini menyebabkan turunnya nilai kandungan nutrisi pakan, karena banyak sumber karbohidrat yang hilang dan kecernaaan protein turun. Keadaan ini terjadi pada tempreratur $55^{\circ} \mathrm{C}$.

\section{Bau}

Dari hasil rekapitulasi penilaian karakter bau dituangkan dalam Tabel 5 berikut ini :

Tabel 4. Rerata karakter fisik bau silase rumput gajah pada berbagai perlakuan

\begin{tabular}{|c|c|c|c|}
\hline \multirow[t]{2}{*}{ No } & \multicolumn{2}{|c|}{ Bau } & \multirow[t]{2}{*}{ Keterangan } \\
\hline & Perlakuan & Rerata skor & \\
\hline 1 & P0 (kontrol) & $1,5^{\mathrm{a}}$ & Berbau busuk/bau rumput \\
\hline 2 & $\mathrm{P} 1$ (tetes) & $4^{b}$ & Berbau harum, manis, dan asam \\
\hline 3 & P2 (dedak) & $2,5^{\mathrm{a}_{j}}$ & Berbau wangi, agak asam \\
\hline 4 & P3 (gula pasir) & $4^{b}$ & Berbau harum, manis, dan asam \\
\hline
\end{tabular}

${ }^{\mathrm{a}, \mathrm{b}}$ Superscript yang berbeda pada kolom yang sama menunjukkan perbedaan yang nyata $(\mathrm{P}<0,05)$

Berdasarkan data diatas diketahui bahwa P1 dan P3 dari bau hampir mendekati dengan ciri bau silase yang baik yaitu berbau harum, manis, dan asam. Namun pada $\mathrm{P} 1$ dan $\mathrm{P} 2$ rasa asam terasa kurang menyengat atau kurang kuat. Sementara pada P1 bau yang dihasilkan mendekati bau busuk, hal ini disebabkan karena pada P1 tidak menambahkan bahan pengawet. Pada P3 terlihat berbeda tidak nyata atau sama saja karena bau yang dikeluarkan hampir sama dengan yang menggunakan pengawet dan tidak menggunakan pengawet.

Menurut Ensminger dan Olentine (1978) bahwa, karakteristik silase yang baik adalah baunya bersih lebih berbau asam, baunya disenangi dibandingkan dengan silase yang jelek. Bau asam yang dihasilkan oleh silase disebabkan dalam proses pembuatan silase bakteri anaerob aktif bekerja menghasilkan asam organik.

\section{Rasa}

Dari hasil rekapitulasi penilaian karakter rasa yang dituangkan dalam Tabel 6 berikut ini : 
Tabel 5. Rerata karakter fisik rasa silase rumput gajah pada berbagai perlakuan

\begin{tabular}{|c|c|c|c|}
\hline \multirow[t]{2}{*}{ No } & \multicolumn{2}{|c|}{ Rasa } & \multirow[t]{2}{*}{ Keterangan } \\
\hline & Perlakuan & Rerata skor & \\
\hline 1 & P0 (kontrol) & $1^{\mathrm{a}}$ & Tidak ada rasa \\
\hline 2 & P1 (tetes) & $4^{b}$ & Rasanya sedikit asam \\
\hline 3 & P2 (dedak) & $1,5^{\mathrm{a}}$ & Tidak ada rasa \\
\hline 4 & P3 (gula pasir) & $3^{b}$ & Rasanya sedikit asam \\
\hline
\end{tabular}

${ }^{\mathrm{a}, \mathrm{b}}$ Superscript yang berbeda pada kolom yang sama menunjukkan perbedaan yang nyata $(\mathrm{P}<0,05)$

Dari data tersebut dapat diketahui bahwa P1 dan P3 dari rasa hampir mendekati dari rasa asam seperti tape karamel namun rasa asam tersebut kurang kuat, P1 dan P2 terlihat berbeda nyata $(\mathrm{P} 0<0,05)$ meskipun rasa yang dihasilkan kurang sempurna yaitu rasa asam seperti tape karamel. Pada P0 dan P2 rasa yang dihasilkan berbeda tidak nyata dimana hampir tidak ada rasanya.

Menurut pendapat Siregar (1996) bahwa, secara umum silase yang baik mempunyai ciri-ciri yaitu rasa dan bau asam, tetapi segar. Selanjutnya Sutrisno (2013), menambahkan bahwa silase yang baik mempunyai rasa dan bau asam tape karamel.

\section{Derajat keasaman (pH)}

Tabel 6. Rerata karakter fisik $\mathrm{pH}$ silase rumput gajah pada berbagai perlakuan

\begin{tabular}{|c|c|c|c|}
\hline \multirow[t]{2}{*}{ No } & \multicolumn{2}{|c|}{ pH } & \multirow[t]{2}{*}{ Keterangan } \\
\hline & Perlakuan & Rerata skor & \\
\hline 1 & P0 (kontrol) & $3^{a}$ & 5 \\
\hline 2 & P1 (tetes) & $5^{b}$ & 4 \\
\hline 3 & P2 (dedak) & $2^{\mathrm{a}}$ & Antara $1(5,5-6)$ dan $3(4,5-5)$ \\
\hline 4 & P3 (gula pasir) & $5^{\mathrm{b}}$ & 4 \\
\hline
\end{tabular}

Pada Tabel diatas dapat dilihat untuk $\mathrm{pH}$ yang paling mendekati ideal adalah pada $\mathrm{P} 1$ dan $\mathrm{P} 3$, dimana $\mathrm{pH}$ yang ideal adalah 3,5-4 dan keduanya berbeda nyata $(\mathrm{P}<0,05)$ dibandingkan $\mathrm{P} 0$ dan $\mathrm{P} 2$. Karakter $\mathrm{pH}$ dengan penambahan dedak (P2) adalah kurang bagus karena masuk skor 2 yaitu antara kriteria 1 (5,5-6) dan 3 (4,5-5) dan $\mathrm{pH}$ pada $\mathrm{P} 2$ adalah 5. Perlakuan tanpa penambahan bahan pengawet atau kontrol (P0) $\mathrm{pH}$ juga kurang bagus karena rata-rata $\mathrm{pH}$ 5. Hal ini sesuai dengan pendapat Matsuhima (1979), yang menyatakan bahan pengawet biasanya ditambahkan untuk mencukupi karbohidrat mudah larut yang berguna dalam fermentasi, terutama untuk menurunkan $\mathrm{pH}$ silase, sedangkan $\mathrm{P} 0$ tidak menggunakan bahan tambahan. 


\section{Kondisi Fisik}

Tabel 7. Rerata karakter kondisi fisik silase rumput gajah pada berbagai perlakuan

\begin{tabular}{|c|c|c|c|}
\hline \multirow[t]{2}{*}{ No } & \multicolumn{2}{|c|}{ Kondisi Fisik } & \multirow[t]{2}{*}{ Keterangan } \\
\hline & Perlakuan & Rerata skor & \\
\hline 1 & P0 (kontrol) & $4^{\mathrm{n}}$ & Antara $3(<1 \%)$ dan $5(0 \%)$ \\
\hline 2 & P1 (tetes) & $4,5^{\mathrm{n}}$ & Antara $3(<1 \%)$ dan $5(0 \%)$ \\
\hline 3 & P2 (dedak) & $3^{\mathrm{n}}$ & Sedikit berjamur $(<1 \%)$ \\
\hline 4 & P3 (gula pasir) & $3,5^{\mathrm{n}}$ & Sedikit berjamur $(<1 \%)$ \\
\hline
\end{tabular}

${ }^{n s}$ Non Signifikan

Berdasarkan data diatas baik P0, P1, P2, dan P3 terlihat tidak signifikan perbedaan fisiknya karena pada kondisi fisik hamper semua ulangan ada jamurnya. Hanya saja pada P1 persentase jamur yang muncul lebih sedikit, namun belum bisa dikatakan bahwa P1 adalah berbeda nyata secara statistik. Kondisi fisik yang baik adalah jika pada silase yang dibuat bebas dari jamur, hal ini sesuai dengan Yulianto (2014) berpendapat bahwa ciri silase yang baik itu adalah apabila bebas dari jamur bahkan apabila ada jamur tidak lebih dari $1 \%$.

\section{KESIMPULAN DAN SARAN}

\section{Kesimpulan}

1. Penurunan protein paling sedikit terjadi pada perlakuan dengan penambahan tetes (P1).

2. Hasil pengamatan organoleptik dari beberapa kriteria yang baik adalah : kriteria tekstur perlakuan penambahan gula pasir (P3), kriteria warna yang paling baik adalah perlakuan penambahan gula pasir (P3), kriteria bau adalah antara perlakuan penambahan tetes (P1) dan gula pasir (P3) sama-sama memiliki bau yang sesuai dengan yang diharapkan, kriteria rasa yang sesuai dengan yang diharapkan adalah perlakuan dengan penambahan tetes (P1), kriteria $\mathrm{pH}$ adalah antara perlakuan penambahan tetes (P1) dan gula pasir (P3), kriteria kondisi fisik yang sesuai adalah perlakuan penambahan tetes (P1).

\section{Saran}

Sebelum membuat silase disarankan memperhatikan tiga faktor yang mempengaruhi dalam pembuatan silase antara lain:

1. Hijauan yang digunakan (segala jenis tumbuhan atau hijauan serta bijian yang disukai oleh ternak, terutama yang mengandung banyak karbohidrat).

2. Zat aditif (aditif digunakan untuk meningkatkan kadar protein dan karbohidrat pada material pakan).

3. Kadar air di dalam hijauan tersebut, dianjurkan hijauan pakan yang berkadar air rendah antara $40 \%$ hingga $50 \%$.

\section{DAFTAR PUSTAKA}

Ahyani, Fika. 2014. Laporan Praktikum

Analisa Proksimat.

http://fikaliverpudlian.blogspot.co.id /2014/10/laporan-praktikum-analisaproksimat.html. Diakses Tanggal 25 Februari 2016.

Akbar, Rizqy. 2015. Silase Jagung. http://www.slideshare.net/RizqyAkb 
ar1/pembuatan-silase.

Diakses

Tanggal 22 Februari 2016

Bio, Zaif. 2009. Metabolisme Hewan. https://zaifbio.wordpress.com/2009/ 03/29/metabolisme-hewan/. Diakses Tanggal 6 April 2016.

Bista. 2013. Uji Karbohidrat Pada Makanan.

http://www.slideshare.net/bistakrenz cool/uji-karbohidrat-padamakanandocx-by-bista. Diakses Tanggal 8 April 2016.

Disnak, Sumbar. 2013. Nutrisi Dan Pakan

Ternak Sapi. http://disnak.sumbarprov.go.id/?disn ak $=$ detail $\& j=11 \& i d=122$. Diakses Tanggal 7 April 2016.

Ensminger and C. G. Olentine. 1978. Feeds and Nutrition Complete. The Ensminger Publishing

Fachrudin, Rahadian, Farida Fathul, Liman. 2012. Evaluasi Kandungan Zat--Zat Makanan Kiambang (Salvinia molesta) Di Waduk Batu Tegi Kecamatan Air Naningan Kabupaten Tanggamus. http://download.portalgaruda.org/art icle.php?article $=48915 \&$ val $=4017$. Diakses Tanggal 5 April 2016.

Kevin. 2011. Definisi Gula. https://kevinnathanael7.wordpress.c om/2011/09/20/definisi-gula/.

Diakses Tanggal 20 Februari 2016.

Kojo M, Raldi, Rustandi, Y. R. L. Tulung, dan S.S.Malalantang. 2015. Pengaruh Penambahan Dedak Padi Dan Tepung Jagung Terhadap Kualitas Fisik Silase Rumput Gajah. http://download.portalgaruda.org/art icle.php?article $=291945 \& \mathrm{val}=1004$ $\&$ title=pengaruh\%20penambahan $\%$ 20dedak\%20padi\%20dan\%20tepun g\%20jagung\%20terhadap\%20kualit as $\% 20$ fisik $\% 20$ silase $\% 20$ rumput $\% 2$ 0gajah\%20\%28pennisetum\%20purp ureumcv.hawaii\%29. Diakses Tanggal 30 Maret 2016.

Matsuhima, J.K. 1979. Feeding Beef Cattle.Sprenger Verlag, Berlin Heidelberg, New York.

Nursholeh. 2015. Laporan Semester Tekhnologi Pengolahan Hijauan Pembuatan Silase. http://Nursholehfapetunja.Blogspot. Co.Id/\#! Diakses Tanggal 28 Februari 2016.

Nursiam, Intan. 2010. Pengertian Silase. https://intannursiam.wordpress.com/ 2010/09/20/pengertian-silase/.

Diakses Tanggal 22 Februari 2016.

Reksohadiprodjo, S. 1988. Pakan ternak Gembala. BPFE, Yogyakarta.

Ridwan, R, S. Ratnakomala, G Kartina dan Y. Widyastuti. 2005. Pengaruh Penambahan Dedak Padi dan Lactobacillus plantarum 1BL-2 dalam Pembuatan Silase Rumput Gajah (Pennisetum purpureum). http://medpet.journal.ipb.ac.id /index.php/mediapeternakan/article/ view/7. Diakses Tanggal 18 Februari 2016.

Saputro, Thomas. 2015 . Rumput Gajah Untuk Pakan Ternak. http://www.ilmuternak.com/2015/03 /rumput-gajah-untuk-pakanternak.html. Diakses Tanggal 8 Januari 2016.

Saputro, Thomas. 2015'. Dedak Padi Untuk Pakan Ternak. http://www.ilmuternak.com/2015/03 /dedak-padi-untuk-pakan- 
ternak.html. Diakses Tanggal 8 Januari 2016.

Saputro, Thomas. 2015c. Cara Mudah Membuat Silase Komplit. http://www.ilmuternak.com/2015/01 /cara-mudah-membuat-silasekomplit.html. Diakses Tanggal 10 Februari 2016

Steel, R. G. D and J. H. Torrie. 1995. Prinsip dan Prosedur Statistik. Terjemahan : B.Sumantri. PT Gramedia Pustaka Utama, Jakarta.

Subekti, Ganjar, Suwarno dan Nur Hidayat. 2013. Penggunaan Beberapa Aditif dan Bakteri Asam Laktat Terhadap Karakteristik Fisik Silase Rumput Gajah Pada Hari Ke-14. http://jos.unsoed.ac.id/index.php/jip/ article/viewFile/665/329. Diakses Tanggal 20 Februari 2016.

Sutrisno, Betha. 2013. Hay Silase dan Jerami Fermantasi. http://bumiternakbetha.blogspot.co.id/2013/08/haysilase-dan-jerami-fermentasi.html. Diakses Tanggal 26 Februari 2016.

Sutrisno. 2013. Nutrisi Pakan Lengkap Rumput Gajah. http://kamicintapeternakan.blogspot. co.id/2015/03/nutrisi-pakanlengkap-rumput-gajah.html.molases. Diakses Tanggal 21 Februari 2016.

Templates, Evo. 2012. Isi Kandungan Gizi Gula Pasir-Komposisi Nutrisi Bahan Makanan. http://www.organisasi.org/1970/01/i si-kandungan-gizi-gula-pasirkomposisi-nutrisi-bahanmakanan.html. Diakses Tanggal 24 2016.
Wijayanto, Edy. 2015. Manfaat Molasses dalam Pakan Ternak Sapi. http://www.sapibagus.com/2015/01/ 26/manfaat-molases-dalam-pakanternak-sapi/. Diakses Tanggal 24 April 2016.

Yovi, Muhammad. 2014. Pengertian Karbohidrat Fungsi Karbohidrat Sumber Karbohidrat. http://woocara.blogspot.co.id/2015/0 4/pengertian-karbohidrat-fungsikarbohidrat-sumberkarbohidrat.html. Diakses Tanggal 11 Januari 2016.

Yulianto. 2014. Inovasi Terkini Teknologi

Ramah Lingkungan. http://m.tabloidsinartani.com/index. php?id=148\&tx_ttnews[tt_news] $=1$ 090\& $\mathrm{cHa}=6 \mathrm{~d} 264 \mathrm{eb} 63 f 03 f 986 \mathrm{a} 2 \mathrm{~b} 64$ 8ba2cc5ad6e. Diakses Tanggal 20 Februari 2016.

Yusriani, Yenni. 2015. Pengawetan Hijauan dengan Cara Silase Untuk Pakan Ternak Ruminansia. http://nad.litbang.pertanian.go.id/ind /index.php/info-teknologi/714pengawetan-hijauan-dengan-carasilase-untuk-pakan-ternakruminansia. Diakses Tanggal 18 Februari 2016. 